\title{
Modelling of planted legume fallows in Western Kenya using WaNuLCAS. (I) Model calibration and validation
}

\author{
A. P. Walker · P. K. Mutuo $\cdot$ M. van Noordwijk • \\ A. Albrecht · G. Cadisch
}

Received: 20 April 2005/Accepted: 26 February 2007 / Published online: 3 May 2007

(C) Springer Science+Business Media B.V. 2007

\begin{abstract}
Poor soil fertility is the biggest obstacle to agricultural productivity in Sub-Saharan Africa. Improved fallows can help to raise agricultural productivity in these systems of low financial capital, however, experimental testing of their potential application domain and design is costly and time consuming. Models can evaluate alternative systems relatively quickly and at relatively low cost, but must first be validated to assess satisfactory simulation of the target systems. Specific climatic, edaphic, crop and fallow growth data was used from five sites in Western Kenya to calibrate and validate simulations of maize and improved fallow growth using the Water, Nutrient and Light Capture in Agroforestry Systems (WaNuLCAS) model. The model predicted continuous maize yields across the sites with an $R^{2}$ of 0.72, an EF (model efficiency) of 0.66 and a $\mathrm{CD}$
\end{abstract}

A. P. Walker · G. Cadisch $(\bowtie)$

Institute of Plant Production and Agroecology in the

Tropics and Subtropics, University of Hohenheim (380a),

70593 Stuttgart, Germany

e-mail: cadisch@uni-hohenheim.de

P. K. Mutuo

The Earth Institute at Columbia University,

c/o ICRAF - Kisumu, P.O. Box 2389, Kisumu, Kenya

M. van Noordwijk

World Agroforestry Centre South-East Asia

(ICRAF-SAE), P.O.Box 161, Bogor 16001, Indonesia

A. Albrecht

I. R. D, Montpellier, France (coefficient of determination) of 2.73, although the default pedotransfer functions (PTF) for volumetric soil water content used in the model had to be substituted for a tropical soils specific PTF before this was achieved. Predicted maize yield was consistently related to fallow biomass (i.e. higher fallow biomass correlated with higher subsequent maize yields) at two sites and the model predicted maize yields following fallow growth from this subset of the data with an $R^{2}$ of 0.42 . This relationship of fallow biomass to subsequent maize yield was not observed across the whole data set due to incomplete fallow litterfall data, factors not included in the model and associated poor model prediction of recycled tree biomass. After site and tree calibration, the model can thus be applied to assess fallow management strategies for sites limited by water and nitrogen.

Keywords Maize - Organic matter modelling · Pedotransfer functions

\section{Introduction}

The highland region of Western Kenya covers an area of $85,000 \mathrm{~km}^{2}, 15 \%$ of the country's land area supporting $12-15$ million people or about $40-50 \%$ of the country's population. The land pressure is high and farms are small varying between 0.5 ha and 2.0 ha with an average of 1.2 ha (David and Swinkels 
1994). Population pressure has forced the traditional slash and burn system of agriculture to be replaced by short term rotational fallow systems or continual cropping systems (Aweto 1981; Brady 1996). In these systems soil nutrients are mined from the system at harvest and the fallow period is too short, if practised at all, to replenish the lost soil fertility. Annual nutrient losses on such small holdings in the west Kenyan highlands were estimated at $100 \mathrm{~kg} \mathrm{~N} \mathrm{ha}^{-1}$ and $10 \mathrm{~kg} \mathrm{P} \mathrm{ha}^{-1}$ (Gathumbi et al. 2002; Shepherd et al. 1996) and in Kenya as a whole the annual per capita food production declined by roughly $1 \%$ per year between 1980 and 1993 (FAO 1996).

Subsistence farming systems in the area are based on intercropping maize [Zea mays (L.)] and a number of bean species [Phaseolus spp. (L.)] as these are the staple food crops of the region, and most of Kenya as a whole (Shepherd et al. 1996). Studies conducted in western Kenya have revealed that maize yields less than $2 \mathrm{Mg} \mathrm{ha}^{-1}$ year $^{-1}$ without fertilization (Swinkels and Franzel 1997). The majority of subsistence farmers in the west Kenyan highlands cannot afford to purchase manufactured chemical inputs in sufficient quantities to significantly improve yields. Therefore soil fertility must be improved without the use of purchased fertilisers. In Sub Saharan Africa (SSA) the major limiting chemical element to crop growth is often nitrogen although phosphorus is also a significant limiting element (Kinyangi et al. 2004).

Nitrogen can be added to the system by the introduction of symbiotic nitrogen fixing plants (Giller and Cadisch 1995) and retrieved from soil below the crop rooting zone by deeper rooting plants (Rowe et al. 1998). Improved fallows are the deliberate planting of fast growing, usually leguminous species, as a fallow in between crop growing cycles (Sanchez 1999). The temporal separation avoids the competition for water and other nutrients between the crop and the legume which is inherent in simultaneous intercropping systems. The choice of a non-crop legume prevents the removal of most of the biologically fixed nitrogen from the management unit that occurs when leguminous crops are used in rotation, due to their high $\mathrm{N}$ harvest index (Giller et al. 1997).

Improved fallows have been demonstrated to improve crop production in subsequent years (Buresh and Tian 1997; Mafongoya and Dzowela 1999) as well as improving a number of other beneficial factors and processes in an agroecosystem such as erosion control (Valentin et al. 2005), control of pests such as striga [Striga hermonthica (Del.) Benth.] and carbon sequestration (Mutuo et al. 2005).

Agroforestry research needs to generate technologies based on scientific principles (Nair 1997). No long term studies have been carried out on improved fallow management strategies for optimal yield returns under specific conditions. Management strategies are likely to be affected by site specific factors such as climate and soil properties as well as characteristics of the fallow species and these interactions need investigation (Szott et al. 1999). These strategies consist of the time of fallow planting, length of fallow phase, time between fallow phases and choice of fallow species. Combined with climatic and edaphic variables these management options add up to a large number of treatments and fallow/crop regimes to investigate. Given the short term nature of funding for research projects, the complexity associated with agro-ecosystem processes, the corresponding expense of measuring every significant variable and the expense of investigating the effects of changing these variables in these diverse, complex systems, computer modelling can yield cost effective, quickly generated, predictions over the short and long term (Matthews 2002).

The WaNuLCAS model (van Noordwijk and Lusiana 1999) was used in this study to investigate the application domains of improved fallow technology under different edaphic and climatic conditions in the highlands of western Kenya, and the influence of these conditions and fallow biomass quality and quantity on the residual benefit of improved fallow to maize yield in relation to management strategy. The WaNuLCAS model was chosen because it simulates dynamic processes in a spatial, plot/field scale environment, i.e. simulation of above and below ground plant growth within a dynamic biophysical environment. It provides for a versatile range of crop, tree and farm management options (van Noordwijk and Lusiana 1999) and we wanted to test the models performance under these specific conditions. Also the Stella ${ }^{\circledR}$ modelling environment (STELLA 1994) in which WaNuLCAS is written made it easy to modify the model such as pedotransfer functions.

Organic matter dynamics within the WaNuLCAS model are based on the CENTURY model devised by Parton et al. (1987) which has five theoretical pools 
of organic matter. The metabolic and structural pools are non-chemically transformed plant residues of relatively fast and slow decomposition rates respectively and the active, slow and passive pools represent various forms of soil organic matter (SOM) that have increasingly slow decomposition rates. The values for these pools must be initialised before the beginning of the simulation. Pedotransfer functions (PTF) are used to derive volumetric soil water content and hydraulic conductivity within WaNuLCAS from more easily measurable soil properties. The PTF for volumetric soil water content is used after van Genuchten (1980) and the PTF for hydrological conductivity after Maulem (1976), the constants for both these functions are derived from functions calibrated by Wösten et al. (1998).

The focus of this paper is to know how much confidence can be placed in the outcomes from this computer model. Confidence is gained by looking at the success of the model's calibration and validation. Rykiel (1996) states that: "Validation is a demonstration that a model within its domain of applicability possesses a satisfactory range of accuracy consistent with the intended application of the model." The predicted data's goodness of fit (GOF) with the experimentally observed data can be measured statistically and acceptable numerical limits can be defined.

The objective of this paper was thus to investigate the ability of the WaNuLCAS model to simulate the impact of improved fallows on subsequent maize yields under a range of environmental conditions, specifically soil texture and rainfall, in Western Kenya.

\section{Materials and methods}

Study site description and fallow systems

This study was based on data collected by the IMProved fALlows by legume plants in eastern and southern Africa (IMPALA) project during 1999-2003 (INCO-DEV 2002). The project used eight experimental sites located in the highlands of western Kenya which cover an area of $85,000 \mathrm{~km}^{2}$. The area receives bimodal rainfall, with long rains occurring from March to June and the short rains from August to November, totalling $1500-1800 \mathrm{~mm}$ annually (Fig. 1, rainfall totalled $106 \%$ of the observed longterm average and the bimodal rainfall pattern was clearly visible in this year), and the long-term mean temperature ranges between 22 and $24^{\circ} \mathrm{C}$. The soils of the region are mostly highly weathered deep volcanic soils with $\mathrm{pH}$ (in water) ranging between 5.0 and 5.8 on most farms (Shepherd et al. 1992). The sites cover a range of soil types with a Ferralsol at Luero; an Acrisol at Lubao and an Arenosol at Teso. The landscape is hilly with slopes ranging between 2 and $8 \%$.

Each site was based at a working farm and the experimental plots were managed by the farmer under the instruction of the research team. At each of the sites, continuous maize and naturally regenerated fallow were grown as controls and two different legume species (Tephrosia candida and Crotalaria paulina) were used as improved fallows, relay cropped with maize and planted in the rotation shown in Fig. 2 at five contrasting sites (Table 1). The
Fig. 1 Daily rainfall at site O3 (Table 2) in 2001 and average monthly (diamonds) rainfall at the IMPALA experimental sites

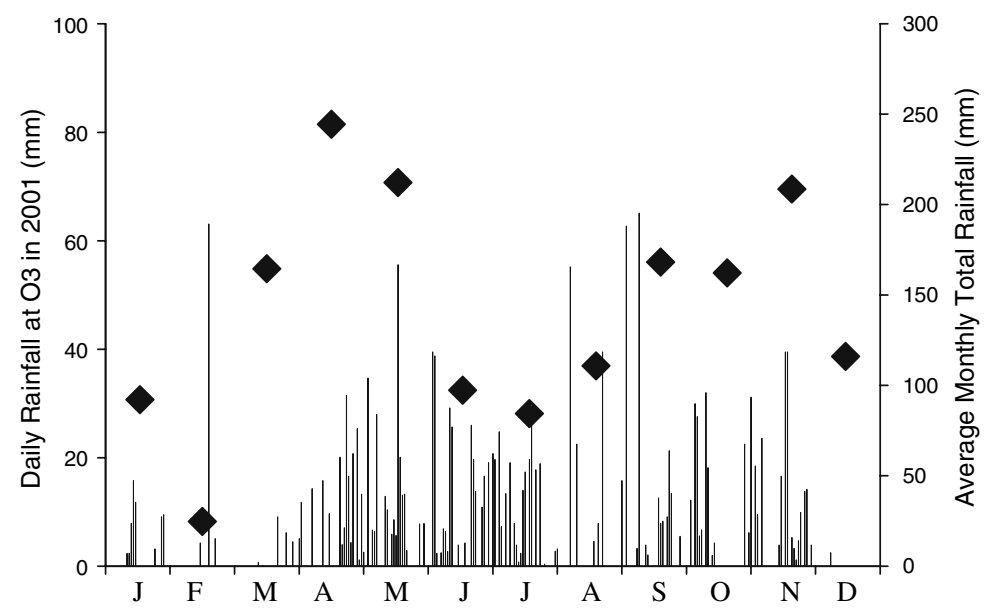


Fig. 2 Rotations used on the IMPALA 'old' (fallow planting 1999) and 'new' (fallow planting 2000) project sites in Kenya. (INCO-DEV 2002)

\begin{tabular}{|c|c|c|c|c|c|c|c|c|}
\hline ROTATION & COUNTRY & PHASE & 1998 & 1999 & 2000 & 2001 & 2002 & 2003 \\
\hline \multirow[t]{2}{*}{1 'OLD' } & \multirow[t]{2}{*}{ KENYA } & FALLOW & & & & & & \\
\hline & & CROP & & & & & & \\
\hline \multirow[t]{2}{*}{1 'NEW' } & \multirow[t]{2}{*}{ KENYA } & FALLOW & & & & & & \\
\hline & & CROP & & & & & & \\
\hline
\end{tabular}

fallow treatments began with an eighteen month fallow period followed by alternating maize in the long rains season with fallow in the short rains season. At some sites the experiments started in 1999 and were labelled the 'old'(O) sites and others began in 2000 and were labelled the 'new'(N) sites. Sites were allocated a number based on the village/group of villages that they were closest to (Table 1). Data were obtained from the IMPALA project for maize yield, detailed fallow biomass (stems, twigs, leaves and roots) yield, nutrient content and quality indicators, soil texture, soil organic matter, soil nutrient content, rainfall patterns and soil water content during 1999-2003 and a subset of these were used to calibrate and others to validate the WaNuLCAS model.

Table 1 Basic soil properties for soil layer $1(0-5 \mathrm{~cm})$ at each site $(\mathrm{O}=$ old sites, $\mathrm{N}=$ new sites; see Fig. 2$)$

\begin{tabular}{|c|c|c|c|c|c|c|}
\hline \multirow[b]{2}{*}{ Soil property } & \multirow[b]{2}{*}{ Village } & \multicolumn{5}{|l|}{ Site } \\
\hline & & $\begin{array}{l}\text { Teso } \\
\text { O1 }\end{array}$ & $\begin{array}{l}\text { Luero } \\
\mathrm{O} 3\end{array}$ & $\begin{array}{l}\text { Lubao }^{\mathrm{a}} \\
\mathrm{O} 4\end{array}$ & $\begin{array}{l}\text { Teso } \\
\text { N1 }\end{array}$ & $\begin{array}{l}\text { Nyabeda }{ }^{\mathrm{a}} \\
\text { N4 }\end{array}$ \\
\hline Clay (\%) & & 19 & 26 & 31 & 16 & 48 \\
\hline Silt (\%) & & 13 & 11 & 27 & 6 & 28 \\
\hline $\begin{array}{l}\text { Bulk Density } \\
\left(\mathrm{g} \mathrm{cm}^{-3}\right)\end{array}$ & & 1.34 & 1.15 & 0.97 & 1.30 & 0.92 \\
\hline $\begin{array}{l}\text { Median Sand } \\
\text { particle } \\
\text { size }(\mu \mathrm{m})\end{array}$ & & 550 & 350 & 350 & 550 & 290 \\
\hline Carbon $(\%)$ & & 0.98 & 1.35 & 1.84 & 0.75 & 2.59 \\
\hline $\begin{array}{l}\text { Total } \\
\text { Nitrogen } \\
(\%)\end{array}$ & & 0.05 & 0.09 & 0.16 & 0.06 & 0.16 \\
\hline $\begin{array}{l}\text { Total } \\
\qquad \text { Nitrogen } \\
\qquad\left(\mathrm{mg} \mathrm{cm}^{-3}\right)\end{array}$ & & 0.79 & 1.02 & 1.52 & 0.81 & 1.46 \\
\hline $\begin{array}{l}\text { Mineral } \\
\text { Nitrogen } \\
\quad\left(\mathrm{mg} \mathrm{cm}^{-3}\right)\end{array}$ & & 0.01 & 0.01 & 0.01 & $\mathrm{n} / \mathrm{a}$ & $\mathrm{n} / \mathrm{a}$ \\
\hline
\end{tabular}

${ }^{a}$ Lubao and Nyabeda are situated close together so the sites from these villages share the same number in their i.d. code
WaNuLCAS model

The WaNuLCAS model was used in this study (van Noordwijk and Lusiana 1999; van Noordwijk et al. 2004). In view of initial poor simulation of water dynamics, the Wösten et al. (1998) pedotransfer functions (PTF) functions used to derive the van Genuchten (1980) constants for volumetric soil water content in the WaNuLCAS model were substituted by those from Hodnett and Tomasella (2002) during this investigation. These functions were calibrated and validated using a database containing soil water content data from a number of soil horizons across the tropics, spanning a wider range of clay and silt proportions than the database used by Wösten et al. (1998) which contained data from soils in the U.K. and the Netherlands only. However, the PTF for hydraulic conductivity was still based on temperate data as no suitable PTFs for the hydraulic conductivity of tropical soils are available (Tomasella, pers. comm.).

Crop growth is based on potential growth (a function of plant size and climate) multiplied by the lowest of the shade, water or nutrient stress factors (i.e. the limiting factor). The water stress factor is expressed as the proportion of transpirational demand met by actual water uptake and the nutrient stress factor is expressed as the ratio of biomass nutrient content to biomass nutrient target, shifted to fall below one when plant nutrient content becomes $80 \%$ of target content to allow for luxury nutrient uptake. Transpirational demand is based on potential growth and the volume of water needed to produce a unit of biomass. Nutrient demand is based on target biomass nutrient concentrations and actual biomass nutrient concentrations. These demands are used to calculate uptake based on root length densities, water/nutrient amounts in soil and effective diffusion constants within a zero sink uptake model (van Noordwijk and Lusiana 1999). Crop yield is allocated a variable proportion of this actual crop growth depending on the crops growth stage. 
Site calibration and validation

One horizontal zone (the width of which was set to $37.5 \mathrm{~cm}$, half the width of the fallow row) in WaNuLCAS was sufficient to simulate the temporal rotation of crop and fallow. Soil layer depths were set to $0.05,0.15,0.3$ and $0.5 \mathrm{~m}$ determined by the various depths at which soil samples were taken. Measured data for each soil layer was entered as was daily rainfall data. Table 1 shows data for the first soil layer at each site. WaNuLCAS was run without phosphorus limitation as $100 \mathrm{~kg} \mathrm{P}^{-1}$ was added each year to the experimental plots. The simulated regimes were set up as shown in Table 2 . Each model run was initiated by a maize crop sown prior to crops that were measured as predicted results.

Sites were calibrated with regimes of continuous maize, a crop that has had its parameters already defined. The length of vegetative and generative maize growth phases were set to observed values. The initial size of the soil organic matter (SOM) pools, which are based on the CENTURY model (Parton et al. 1987), and cultivar specific maize parameters (potential growth rate and remobilizable fraction of biomass) were determined by iteratively fitting predicted to observed continuous maize grain yields at $15 \%$ moisture content. The final values for the calibration of initial organic matter pool sizes were site specific while the maize parameters were maintained across all sites. This process of fitting causes a loss of one degree of freedom to the statistical assessment of the model.

Tree species calibration and validation

Allometric equations to relate tree biomass to stem diameter were used to simulate tree growth, (van Noordwijk and Mulia 2005). Water and nutrient uptake was calculated from root length densities obtained by simulating tree root growth (WaNuLCAS root growth type 2) as opposed to using constant root length densities (WaNuLCAS root growth type 0 and 1) which does not allocate biomass to roots (van Noordwijk and van de Geijn 1996). Tree species Tephrosia candida (Roxb.) D.C. and Crotalaria paulina (Schrank) parameters were calibrated individually at each site as tree growth was influenced by additional environmental factors (e.g. disease, hard
Table 2 Calendar of activities during site and tree calibration entered in WaNuLCAS. Maize harvest date not shown as it was predicted by the model at biological maturity of maize

\begin{tabular}{|c|c|c|c|c|c|}
\hline \multicolumn{2}{|l|}{ Year } & \multirow{2}{*}{$\begin{array}{l}\text { WaNuLCAS } \\
\text { year }\end{array}$} & \multirow{2}{*}{$\begin{array}{l}\text { Day } \\
\text { of } \\
\text { year }\end{array}$} & \multicolumn{2}{|l|}{ Activity } \\
\hline $\begin{array}{l}\text { Old } \\
\text { Trials }\end{array}$ & $\begin{array}{l}\text { New } \\
\text { Trials }\end{array}$ & & & $\begin{array}{l}\text { Continuous } \\
\text { Maize }\end{array}$ & $\begin{array}{l}\text { Fallow } \\
\text { Regime }\end{array}$ \\
\hline \multirow[t]{2}{*}{1999} & 2000 & 0 & 90 & & $\begin{array}{l}\text { Plant } \\
\text { maize }^{\mathrm{a}}\end{array}$ \\
\hline & & 0 & 190 & & $\begin{array}{l}\text { Plant } \\
\text { fallow }\end{array}$ \\
\hline \multirow[t]{2}{*}{2000} & 2001 & 1 & 90 & $\begin{array}{l}\text { Plant } \\
\text { maize }^{\mathrm{a}}\end{array}$ & \\
\hline & & 1 & 270 & $\begin{array}{l}\text { Plant } \\
\text { maize }^{\mathrm{a}}\end{array}$ & \\
\hline \multirow[t]{4}{*}{2001} & 2002 & 2 & 58 & & $\begin{array}{l}\text { Harvest } \\
\text { fallow }\end{array}$ \\
\hline & & 2 & 90 & $\begin{array}{l}\text { Plant } \\
\text { maize }\end{array}$ & $\begin{array}{l}\text { Plant } \\
\text { maize }\end{array}$ \\
\hline & & 2 & 190 & & $\begin{array}{l}\text { Plant } \\
\text { fallow }\end{array}$ \\
\hline & & 2 & 270 & $\begin{array}{l}\text { Plant } \\
\text { maize }\end{array}$ & \\
\hline \multirow[t]{4}{*}{2002} & 2003 & 3 & 58 & & $\begin{array}{l}\text { Harvest } \\
\text { fallow }\end{array}$ \\
\hline & & 3 & 90 & $\begin{array}{l}\text { Plant } \\
\text { maize }\end{array}$ & $\begin{array}{l}\text { Plant } \\
\text { maize }\end{array}$ \\
\hline & & 3 & 190 & & $\begin{array}{l}\text { Plant } \\
\text { fallow }\end{array}$ \\
\hline & & 3 & 270 & $\begin{array}{l}\text { Plant } \\
\text { maize }\end{array}$ & \\
\hline \multirow[t]{3}{*}{2003} & End & 4 & 58 & & $\begin{array}{l}\text { Harvest } \\
\text { fallow }\end{array}$ \\
\hline & & 4 & 90 & $\begin{array}{l}\text { Plant } \\
\text { maize }\end{array}$ & $\begin{array}{l}\text { Plant } \\
\text { maize }\end{array}$ \\
\hline & & 4 & 270 & $\begin{array}{l}\text { Plant } \\
\text { maize }\end{array}$ & \\
\hline
\end{tabular}

${ }^{\text {a }}$ Pre-crop

pan) that were not considered by the model. This individual calibration means that the tree parameters are not generally applicable, however for the validation of the model in this situation it was the relationship between tree growth and subsequent maize yield that was important.

Measured parameters for tree species were in-put, including nutrient contents of various parts of the plant and litter quality (Table 3). Other parameters such as maximum growth rate, maximum daily mobilizable fraction of growth reserves, $\mathrm{N}_{2}$ fixation and FBA constants were calibrated by fitting 
Table $3 T$. candida and $C$. paulina tree input parameters for WaNuLCAS model.

\begin{tabular}{|c|c|c|c|}
\hline \multirow[t]{2}{*}{ Tree Parameter } & & \multicolumn{2}{|l|}{ Species } \\
\hline & & $\begin{array}{l}T . \\
\text { candida }\end{array}$ & $\begin{array}{l}C . \\
\text { paulina }\end{array}$ \\
\hline \multirow{4}{*}{$\begin{array}{l}\text { Nutrient } \\
\text { concentrations }\end{array}$} & $\mathrm{N}$ in leaves $\left(\mathrm{g} \mathrm{g}^{-1}\right)$ & 0.035 & 0.035 \\
\hline & $\mathrm{P}$ in leaves $\left(\mathrm{g} \mathrm{g}^{-1}\right)$ & 0.002 & 0.002 \\
\hline & $\mathrm{N}$ in twig $\left(\mathrm{g} \mathrm{g}^{-1}\right)$ & 0.015 & 0.015 \\
\hline & $\mathrm{P}$ in twig $\left(\mathrm{g} \mathrm{g}^{-1}\right)$ & 0.001 & 0.001 \\
\hline $\mathrm{N}_{2}$ fixation & $\begin{array}{l}\text { Proportion of } \mathrm{N} \\
\text { from fixation }\end{array}$ & 0.90 & 0.74 \\
\hline \multirow[t]{4}{*}{ Quality } & $\begin{array}{l}\text { Polyphenol fraction } \\
\text { in leaves }\end{array}$ & 0.02 & 0.02 \\
\hline & $\begin{array}{l}\text { Polyphenol fraction } \\
\text { in litter }\end{array}$ & 0.01 & 0.01 \\
\hline & $\begin{array}{l}\text { Lignin fraction in } \\
\text { leaves }\end{array}$ & 0.20 & 0.14 \\
\hline & $\begin{array}{l}\text { Lignin fraction } \\
\text { in litter }\end{array}$ & 0.23 & 0.16 \\
\hline
\end{tabular}

predicted to observed relative biomass fractions (stem and leaf + twig) at each site. Biomass $\mathrm{N}$ content and the root fraction of biomass were calibrated using data from the $\mathrm{O} 3$ site only and litterfall throughout the 18 month initial fallow period was calibrated at both the $\mathrm{N}$ sites only. Where parameters that related to specific outputs were not calibrated at all sites e.g. litterfall, the calibrated parameter was applied across the rest of the sites. Confidence in the validity of the model was assessed through predicted to observed maize GOF and predicted maize yield and tree biomass relationships.

\section{Statistical analysis}

A linear regression between observed and predicted data was performed. The $R^{2}$ was used as a measure of how close to a linear 1:1 relationship observed to predicted results were. Additional GOF statistics (Loague and Green 1991) that have been specifically designed for model goodness of fit were also applied:

Modelling efficiency (EF);

$\mathrm{EF}=\left(\sum_{i=1}^{n}\left(O_{i}-\bar{O}\right)^{2}-\sum_{i=1}^{n}\left(P_{i}-O_{i}\right)\right)^{2} / \sum_{i=1}^{n}\left(O_{i}-\bar{O}\right)^{2}$
Coefficient of determination (CD);

$$
\mathrm{CD}=\sum_{i=1}^{n}\left(O_{i}-\bar{O}\right)^{2} / \sum_{i=1}^{n}\left(P_{i}-\bar{O}\right)^{2}
$$

Root mean square error (RMSE);

$$
\begin{aligned}
& \text { RMSE }=\left[\sum_{i=1}^{n}\left(P_{i}-\bar{O}\right)^{2} / n\right]^{0.5} \cdot \frac{100}{\bar{O}} \\
& \text { Maximum error }(\mathrm{ME}) ;
\end{aligned}
$$

$\mathrm{ME}=\operatorname{Max} \mid P_{i}-O_{i} \|_{i=1}^{n}$

where $P_{i}$ are the predicted values; $O_{i}$ are the observed values; $n$ is the number of samples; and $\bar{O}$ is the mean of the observed data. These statistics are more descriptive of the models GOF. EF tells us how well the model is performing in prediction, a value of one indicates a perfect one-to-one relationship and any negative value tells us that the model is worse at predicting observed data than when using the mean of observed values to predict the data. $\mathrm{CD}$ is similar to $R^{2}$ as it measures the proportion of the total variance of observed data explained by predicted data, a perfect fit also being one with a lower limit of zero and upper limit of infinity. It tells us whether the model is over predicting (a value under one) or under predicting (a value over one). RMSE is the root of the mean square error expressed as a percentage of the observed mean i.e. the average error of predicted results and the ME is the single greatest error between a corresponding observed and predicted result. The regressions were carried out using SigmaPlot ${ }^{\circledR}$ (SPSS) and the GOF statistics using an Excel ${ }^{\circledR}$ spreadsheet containing functions from Loage and Green (1991).

In accordance with Rykiel (1996), for the simulations to be accepted an $R^{2}$ value for calibration and validation of 0.5 was considered necessary to indicate a good predicted to observed relationship. A CD value between 0.5 and 2 was considered necessary and, although sought, an EF value above zero was not considered necessary as a satisfactory GOF relationship between observed and predicted results. 


\section{Results and discussion}

Model modification

A regression between maize yields and rainfall in both $\mathrm{O} 1$ and $\mathrm{N} 1$ sites revealed significant linear relationships (Fig. 3a), the regression lines were fit for each site individually due to the wide environmental and managerial inter site variation. However, predicted maize yields were not responsive to variations in rainfall using the Wösten et al. (1998) pedotransfer functions (PTFs) (Fig. 3b). In view of these results, we investigated the substitution of the PTFs from Wösten et al. (1998) with those of Hodnett and Tomasella (2002), as the latter were calibrated and validated using a tropical soils database. The substitution of these PTFs increased the predicted to observed GOF $R^{2}$ for continuous maize yield from 0.04 to 0.96 when calibrating soil organic matter pools separately for each PTF simulation (Fig. 3c). Although these individual organic matter calibrations may have unwittingly biased results in favour of the Hodnett and Tomasella (2002) PTFs, it is unlikely as the organic matter calibrations had a large effect on absolute maize yields and only a small effect on variation between maize yields. Indeed the substitution of the PTFs had the effect of making the variation in simulated maize yields at the $\mathrm{O} 1$ and $\mathrm{N} 1$ sites strongly related to rainfall in the particular growing season (Fig. 3c). The outlier in observed data (Fig. 3a) is a short rains yield, due to total crop failure and its removal from the data set improves the $R^{2}$ from 0.49 to 0.91 .
Interestingly the model predicted maize yields in the long rains seasons significantly better than in the short rains seasons (Fig. 4). The statistical GOF values for the long rains seasons were good with the model producing $0.72,0.63$ and 2.22 from the $R^{2}$, EF and CD tests, respectively, and low error values. In contrast, the prediction of maize yields for the short rain seasons were poor with values of $0.28,0.12$ and 2.60 from the $R^{2}, \mathrm{EF}$ and CD tests, respectively, and high error values.

The overall strong correlation of simulated maize yields to rainfall yet the poor prediction of maize yields during the short rains seasons compared to the long rains seasons (Fig. 4) implies that absolute rainfall was not the only reason for the difference in yields between the short rains seasons and the long rains seasons. Factors such as the distribution of rainfall within the season were likely to have had a role in limitation of observed maize yields. However, the WaNuLCAS model only stops plant growth at low soil water contents and does not simulate the physiological processes associated with water stress, such as cell damage, that would slow a plants recovery or stunt ear development even after relief from the water stress.

Kinyangi et al. (2004) also encountered general over-prediction of continuous maize total biomass (particularly in the short rains season) under their $60 \mathrm{~kg} \mathrm{~N}^{-1}$ plus $0 \mathrm{~kg} \mathrm{P} \mathrm{ha}^{-1}$ treatment using the Agricultural Production SIMulator (APSIM) model to simulate a fertilisation experiment on a phosphorus and nitrogen limited system in Western Kenya. They attributed lower observed maize biomass during the
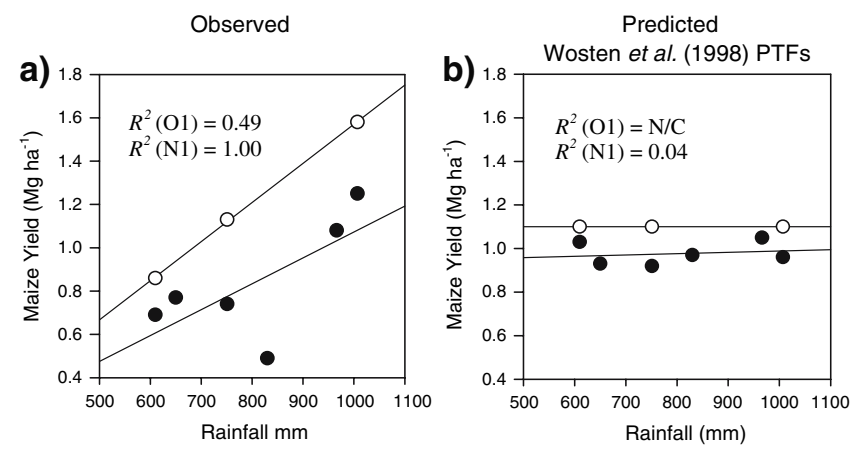

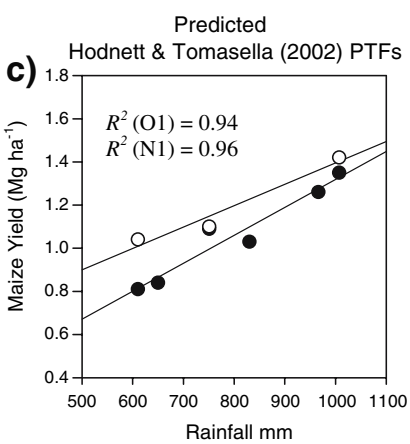

allow for environmental and managerial differences between the two sites. N/C means non-calculable as the regression is a perfectly horizontal line
Fig. 3 Scatter graph of maize yield against rainfall in the respective growing season at both Teso sites, $\mathrm{O} 1(\bullet)$ and N1 (०), for observed and predicted results. The lines are regressions for each site and are carried out independantly to 
Fig. 4 Scatter graphs of predicted against observed continuous maize yields for site calibration across all sites. The yields from the long rains and short rains season are presented separately. The solid line represents the regression line and the dashed line the $1: 1$ line
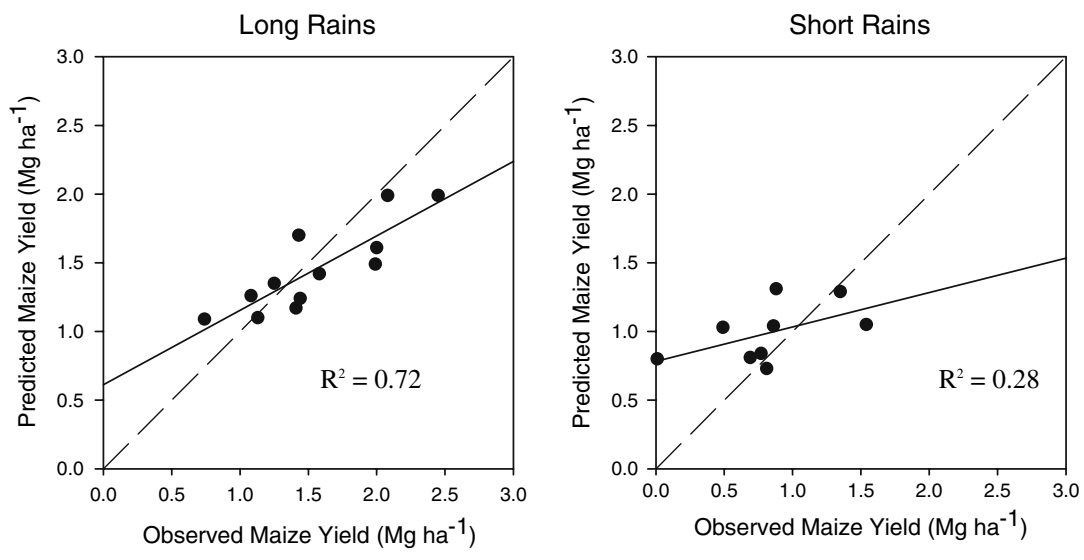

short rains season to a nitrogen limitation effect as nitrogen was applied to the plots at the beginning of every long rains season and not at the beginning of the short rains season. Also the model indicated that nitrogen was the main stress governing this interaction and that water was not at all limiting. However, they had no treatment without $\mathrm{N}$ addition and it is unclear as to whether they used specific observed season to season rainfalls for their simulation.

Site calibration

The initial $\mathrm{N}$ content of each site's soil organic matter pools was calibrated using continuous maize yields without external mineral $\mathrm{N}$ supply (Table 4). This was done based on the measured organic soil $\mathrm{N}$ and iteratively changing the proportions of each pool until the best GOF of continuous maize results were achieved since plants had to rely on nutrient supply from soil organic matter. All sites had the initial $\mathrm{N}$ values of the two litter pools set at zero as the experimental plots were cleared of all litter before the

Table 4 Calibrated initial starting model soil organic matter (SOM) pool sizes.

\begin{tabular}{lllr}
\hline Site & \multicolumn{3}{l}{ Soil organic matter pool, $\mathrm{mg} \mathrm{N} \mathrm{cm}^{-3}(\%$ of total) } \\
\cline { 2 - 4 } & Active & Slow & Passive \\
\hline O1 & $0.015(2)$ & $0.60(74)$ & $0.20(24)$ \\
O3 & $0.020(2)$ & $0.55(54)$ & $0.44(44)$ \\
O4 & $0.200(13)$ & $0.80(53)$ & $0.52(34)$ \\
N1 & $0.005(0.4)$ & $1.30(93)$ & $0.10(7)$ \\
N4 & $0.100(6)$ & $1.20(77)$ & $0.25(17)$ \\
\hline
\end{tabular}

Values in parenthesis are \% of total SOM planting of the initial fallow. The active pools ranged between 0.4 and $13 \%$ of total organic nitrogen the lowest percentage being present in the sandiest soils and the highest in the more heavily clay soils, this may be representative of the higher amount of biological activity and protection mechanisms in clay soils. The slow pools ranged between 53 and $93 \%$ of total organic nitrogen and appeared to be quite high compared to the usual recommendations (Woomer 1993) for the initial size of these pools and the organic matter fractions they represent. These high slow pool fractions may have been compensating for low simulated rates of organic matter decomposition, a problem encountered by Diels et al. (2005) who had to double organic matter decomposition rates over and above the accepted rate increase due to increased temperatures when validating the ROTHC model against organic matter dynamics in the subhumid tropical climate of south western Nigeria. Also, at times simulated water stress may have been artificially high and nitrogen levels may have needed to be artificially high to compensate. Though we used PTFs calibrated for tropical soils to model volumetric soil water content, overly high water limitation could have been due to the PTFs for hydrological conductivity having been calibrated with only temperate soils' data. Tropical soils are often more highly structured than temperate soils (Mutuo 2004; Sitompul et al. 2000) allowing faster movement of water through the soils and hence higher infiltration rates. Critical to the hydrological conductivity equation is the value of saturated hydrological conductivity, $K_{\text {sat }}$ which could be calibrated in a future study for these soils using GOF for surface run off. 
Maximum maize growth per day was calibrated to $0.025 \mathrm{~kg} \mathrm{~m}^{-2}$ and the maximum proportion of crop biomass remobilised to storage component (i.e. grain) per day was calibrated to 0.025 . The magnitude of maize yields were strongly affected by the size of organic matter pools, particularly the slow pool, and a method to measure the magnitude of each of these pools would have been useful in improving the validity of the model. Work is currently in progress to develop methods to measure initial organic matter fractions and simulation of organic matter decomposition based on soil fractionation (Mutuo et al. 2006) and near infra-red spectroscopy (Shepherd 2004).

The results presented in Table 5 are the goodness of fit (GOF) test statistics for the Eqs. 1-4 and the $R^{2}$ value $(0.72)$ for validation of the WaNuLCAS model based on continuous maize yield data across all of the IMPALA project sites (Fig. 5). The results indicate a good ability of the model to predict maize yields across the sites under these limited conditions and management regimes. However, the model underpredicted maize yields at high continuous maize yields and over-predicted at lower observed continuous maize yields. The under-prediction of higher observed maize yields was thought to be due to overly strong water limitation and under-prediction of nitrogen uptake in the model. Maize yields in relation to water limitation and soil PTFs has been discussed above. Under-simulation of nitrogen uptake was indicated by the discrepancy between limited data on observed maize nitrogen concentration, $1.25 \%$ (stover at O3 in long rains 2001) and simulated maize nitrogen content, $0.5 \%$. Under prediction of maize nitrogen uptake could be accounted for by the omission of the process of nitrate mass flow from the WaNuLCAS model, an important process in the delivery of nitrogen to plant roots (Marschner 1986).

Table 5 Model calibration statistics for continuous maize yields across all sites together

\begin{tabular}{llllll}
\hline Site & $R^{2}$ & EF & CD & RMSE \\
$1^{\mathrm{a}}$ & $1^{\mathrm{a}}$ & $\begin{array}{l}\mathrm{ME} \\
0^{\mathrm{a}}(\%)\end{array}$ & $0^{\mathrm{a}}\left(\mathrm{Mg} \mathrm{ha}^{-1}\right)$ \\
\hline All Sites & 0.72 & 0.66 & 2.73 & 27 & 0.79 \\
\hline
\end{tabular}

a Best possible result indicating the value for a perfect fit between observed and predicted maize yields, in the case of $R^{2}$ it is a perfect fit between the variation of observed and predicted results

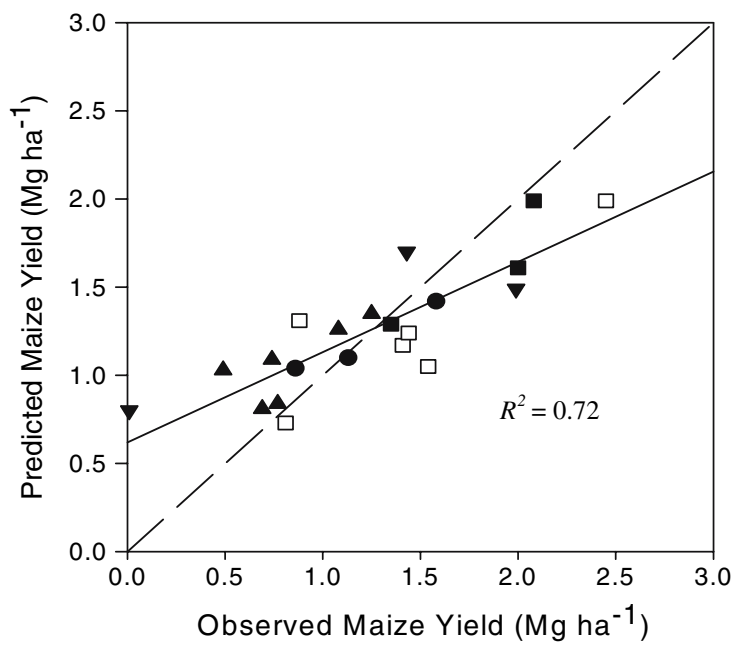

Fig. 5 Scatter graph of predicted against observed maize yields for site calibration of continuous maize with all sites

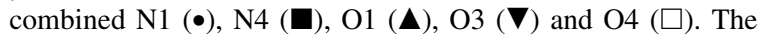
solid line represents the regression line and the dashed line the $1: 1$ line

Tree calibration and validation of fallow influence on maize yield

Calibration of tree growth parameters at a single site and then use of these parameters to predict tree growth at the other sites produced poor GOF statistics (Table 6) and this was the reason for calibration of tree growth parameters at each individual site. Tree growth parameters were calibrated based on biomass produced in the first 18 month fallow season, consequently simulated total leaf, pod and twig ( $<2 \mathrm{~mm}$ in diameter) biomass (LT biomass) and wood biomass for this period had good GOF statistics (Table 6, e.g. $R^{2}$ 0.84). Subsequent fallow seasons were used to validate simulation of fallow growth. Wood biomass was also well predicted across all the seasons, however, this was not the case for LT biomass where there was significant deviation away from the good GOF results of the first fallow season, the $R^{2}$ dropped from 0.84 to 0.34 ; EF from 0.69 to 0.22 but the $C D$ did not change significantly. This indicates that prediction of LT biomass was not good and although the GOF results indicate some relationship, this is only a manifestation of the calibration during the first fallow period. Prediction of LT biomass production was confounded at one site (O3) by the fact that $C$. paulina was attacked by caterpillars in the second fallow season, stripping the plants 
Table 6 GOF statistics for tree biomass calibration and maize yield validation across all sites. LT is leaf, twig and pod combined biomass

\begin{tabular}{|c|c|c|c|c|c|c|}
\hline & & $\begin{array}{l}R^{2} \\
1^{\mathrm{a}}\end{array}$ & $\begin{array}{l}\mathrm{EF} \\
1^{\mathrm{a}}\end{array}$ & $\begin{array}{l}\mathrm{CD} \\
1^{\mathrm{a}}\end{array}$ & $\begin{array}{l}\text { RMSE } \\
0^{\mathrm{a}}(\%)\end{array}$ & $\begin{array}{l}\mathrm{ME} \\
0^{\mathrm{a}}\left(\mathrm{Mg} \mathrm{ha}^{-1}\right)\end{array}$ \\
\hline \multirow[t]{3}{*}{ 1st fallow period } & $\mathrm{LT}^{\mathrm{A}}$ & 0.14 & -2.16 & 0.37 & 109 & 4.81 \\
\hline & $\mathrm{LT}^{\mathrm{B}}$ & 0.84 & 0.69 & 1.34 & 34 & 2.01 \\
\hline & Maize $^{B}$ & 0.01 & -0.47 & 1.34 & 34 & 2.19 \\
\hline \multirow[t]{2}{*}{ 2nd and 3rd fallow period } & Wood $^{\text {B }}$ & 0.77 & 0.76 & 1.23 & 34 & 2.80 \\
\hline & $\mathrm{LT}^{\mathrm{B}}$ & 0.00 & -0.60 & 1.92 & 72 & 3.25 \\
\hline \multirow[t]{3}{*}{ All fallow periods } & Wood $^{\text {B }}$ & 0.94 & 0.94 & 1.15 & 22 & 6.83 \\
\hline & $\mathrm{LT}^{\mathrm{B}}$ & 0.34 & 0.22 & 1.35 & 54 & 3.25 \\
\hline & Maize $^{B}$ & 0.19 & 0.02 & 2.19 & 43 & 2.83 \\
\hline
\end{tabular}

A—calibration using $\mathrm{O} 3$ site only; B-individual site calibration. ${ }^{\text {a }}$ Best possible result indicating the value for a perfect fit between observed and predicted results

of most of their leaves. For an unknown reason fallow trees at the $\mathrm{O} 4$ site also grew poorly in the second and third seasons (INCO-DEV 2002). Removal of these outliers from the data set did significantly improve fallow LT biomass GOF across all seasons, however this was not due to an improvement of the GOF for LT biomass prediction in the second and third seasons which remained poor (Table 6). It is clear from the results for fallow season two and three that simulation of LT biomass was not at all accurate.

Litterfall throughout the fallow season was measured only at the new sites and only in the first fallow season, therefore without data the model could not be fully calibrated. LT biomass was strongly influenced by litterfall and the lack of calibrated litterfall may be the reason for the poor simulation of LT biomass. Having been calibrated individually for each site the parameters for simulation of tree growth are not rigorous to be universally applied and therefore are not included here.

There was good correlation $\left(R^{2}\right.$ of 0.51$)$ between simulated maize yields following the first fallow season and simulated tree leaf plus twig biomass from the first fallow season (Fig. 6), a correlation which is consistent with results of previous studies (Ndufa 2001; Szott et al. 1999). Although, in the IMPALA experimental study (INCO-DEV 2002) there was no consistent linear relationship $\left(R^{2}=0.02\right)$ between maize yield of the following crop and LT data when results across all the sites were combined.

However, there was a reasonable relationship between cumulative fallow LT biomass and the following maize yields at the $\mathrm{N}$ sites (Fig. 7).

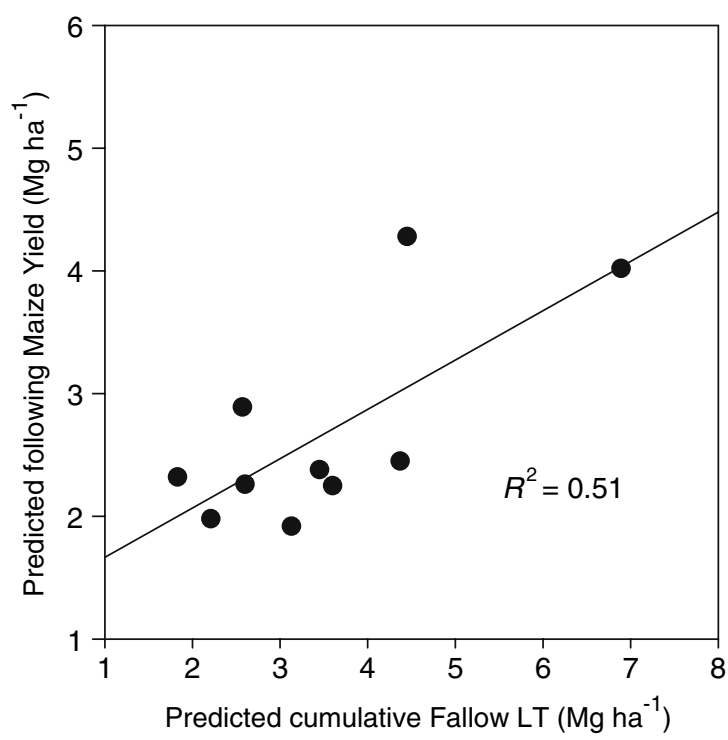

Fig. 6 Predicted maize yield following first fallow period against predicted fallow leaf plus twig biomass (LT) of the first fallow season

Indicative of the benefit of good litterfall calibration (litterfall was only measured at the $\mathrm{N}$ sites) there was reasonable prediction of maize yields (Fig. 8) when the $\mathrm{N}$ sites alone were tested for GOF. Although with an $R^{2}$ of 0.42 and an EF of -0.12 the GOF results were just below what had been suggested for confidence in the models validity.

The poor GOF of predicted to observed maize yields across all the sites (Table 6) may have been down to lack of measurement of litterfall during the fallow phase which would have also had a large influence on observed maize yields. This is an 


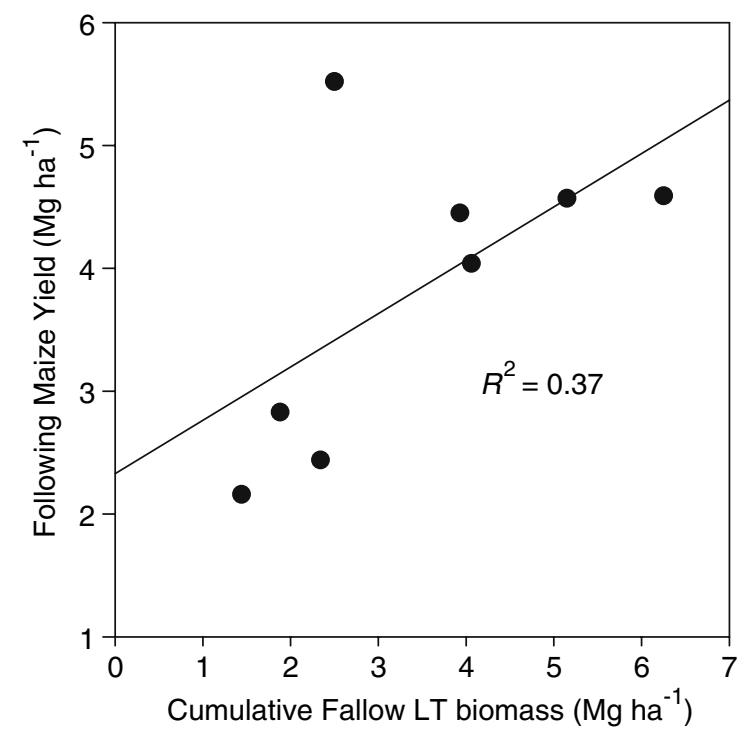

Fig. 7 Scatter plot of observed maize yield data against cumulative fallow biomass at both the $\mathrm{N}$ sites using both fallow species (Tephrosia candida and Crotalaria paulina)

important issue in modelling in that models can only be as complete and accurate as the data sets used to parameterise them. The absence of a strong linear relationship between observed fallow biomass and following maize yields (for all sites considered together) also indicates that there may have been influences on maize yields at the experimental sites, other than simply fallow biomass, that were not

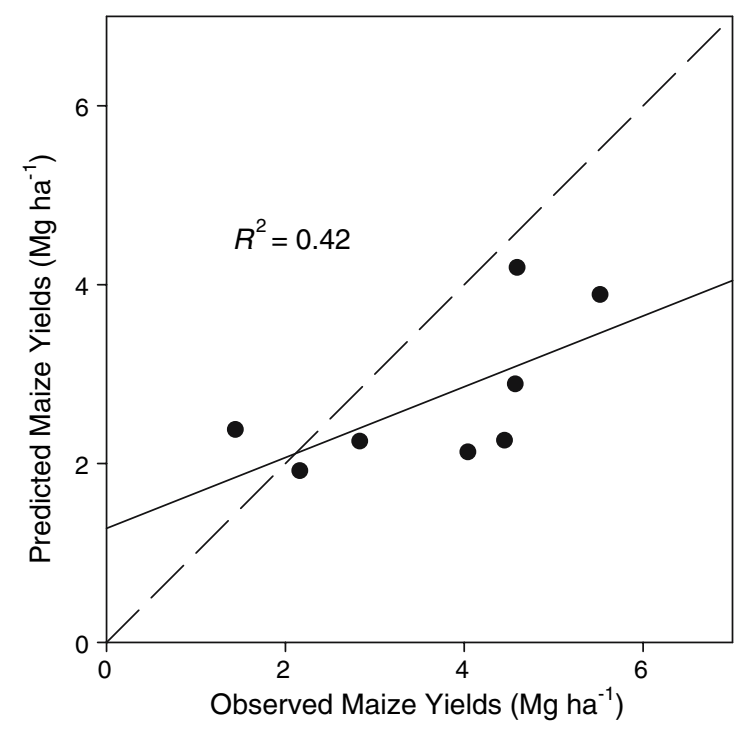

Fig. 8 Observed vs. predicted maize yield following first fallow treatments at the $\mathrm{N}$ sites (Fig. 2) only simulated by the model i.e. some of these specific sites were out of the application domain of the model. This highlights the real variation in limiting factors (other than simply nitrogen, phosphorus and water) associated with farmers' fields in resource poor environments (e.g. pests, hard pan, diseases, micronutrient deficiencies, etc).

\section{Conclusions}

Although prediction of continuous maize yields had a narrower range than those observed experimentally, prediction of continuous maize yields were accurate which allowed confidence in the validity of the model when simulating maize growth in response to rainfall and soil texture.

Fallow biomass calibration was incomplete due to lack of litterfall data and certain observed environmental factors not being simulated by the model, therefore overall fallow biomass prediction was poor. Poor fallow biomass calibration confounded prediction of maize yields following fallow treatments, but at sites where calibration of fallow biomass was better prediction of maize yields was also improved. In most cases simulated maize yields correlated well with simulated cumulative tree leaf, twig and litter biomass. This correlation was observed at both the $\mathrm{N}$ sites and has been widely recognised in the literature.

For wider application it is necessary to ensure that the model is only applied within its designed boundaries, i.e. simulation of water, nitrogen and phosphorus limitations. Within these boundaries the model, after calibration and with the modified pedotransfer function, performed acceptably for predicting maize growth and its response to organic inputs, rainfall and soil texture and can thus be used to investigate alternative fallow management options. However, the model cannot be used to assess absolute yields at any site in Western Kenya as crop and tree performance were limited by additional factors not considered in the model.

\section{References}

Aweto AO (1981) Secondary succession and soil fertility restoration in south-western Nigeria. II Soil fertility restoration. J Ecol 69:609-614

Brady NC (1996) Alternatives to slash-and-burn: a global imperative. Agric, Ecosys Environ 58:3-11 
Buresh RJ, Tian G (1997) Soil improvement by trees in subSaharan Africa. Agrofor Sys 38:51-76

David S and Swinkels RA (1994) Socio-economic characteristics of households engaged in agroforestry technology testing in western Kenya. Rep. No. 78 International Centre for Research in Agroforestry (ICRAF), Nairobi, Kenya

Diels J, Vanlauwe B, van de Meersch M K, Sanginga N and Merckx R (2005) Long-term soil organic carbon dynamics in a subhumid tropical climate: ${ }^{13} \mathrm{C}$ data in mixed $\mathrm{C}_{3} / \mathrm{C}_{4}$ cropping and modelling with ROTHC. Soil Biol Biochem 36:1739-1750

FAO (1996) Soil fertility initiative. Food and Agriculture Organization of the United Nations, Rome, Italy

Gathumbi SM, Cadisch G, Giller KE (2002) ${ }^{15} \mathrm{~N}$ natural abundance as a tool for assessing $\mathrm{N}_{2}$ - fixation of herbaceous, shrub and tree legumes in improved fallows. Soil Biology and Biochemistry 34:1059-1071

Giller KE, Cadisch G (1995) Future benefits from biological nitrogen fixation: An ecological approach to agriculture. Plant Soil 174:255-277

Giller KE, Cadisch G, Ehaliotis C, Adams E, Sakala WD, Mafongoya PL (1997) Building soil nitrogen capital in Africa. In: Buresh RJ, Sanchez PA, Calhoun F (eds) Replenishing soil fertility in Africa. ASSA, CSSA, SSSA, Madison, Wisconsin, pp 151-192

Hodnett MG, Tomasella J (2002) Marked differences between van Genuchten soil water-retention parameters for temperate and tropical soils: a new water-retention pedotransfer functions developed for tropical soils. Geoderma 108:155-180

INCO-DEV (2002) Improved fallows by legume plants (trees, shrubs and grasses) in Eastern and Southern Africa. Second Annual Report. INCO-DEV: International Cooperation with Developing Countries. EU, Brussels, Belgium

Kinyangi J, Delve RJ and Probert ME (2004) Testing the APSIM Model with Data from a Phosphorus and Nitrogen Replenishment Experiment on an Oxisol in Western Kenya. In: Delve RJ, Probert ME (eds) Modelling nutrient management in tropical cropping systems. ACIAR Proceedings No. 114, Canberra, Australia, pp 101-109

Loage K, Green RE (1991) Statistical and graphical methods for evaluating solute transport models: Overview and application. J Contaminant Hydrol 7:51-73

Mafongoya PL, Dzowela BH (1999) Biomass production of tree fallows and their residual effect on maize in Zimbabwe. Agrofor Sys 47:139-151

Marschner H (1986) Mineral nutrition of higher plants. Academic Press, London

Matthews RB (2002) Introduction. In: Matthews RB, Stephens W (eds) Crop-Soil simulation models: applications in developing countries. CAB International, Wallingford, Oxon

Maulem Y (1976) A new model for predicting the hydraulic conductivity of unsaturated porous media. Water Resour Res 12:513-522

Mutuo PK (2004) Potential of improved tropical legume fallows and zero tillage practices for soil organic carbon sequestration. PhD thesis, Department Agricultural Sciences. University of London, Wye Campus, Wye, UK, p 283
Mutuo PK, Cadisch G, Albrecht A, Palm CA, Verchot L (2005) Potential of agroforestry for carbon sequestration and mitigation of greenhouse gas emissions from soils in the tropics. Nutr Cycl Agroecosyst 71:43-54

Mutuo PK, Shepherd KD, Albrecht A, Cadisch G (2006) Prediction of Carbon Mineralization Rates from Soil Physical Fractions Using Diffuse Reflectance Spectroscopy. Soil Biol Biochem 38:1658-1664

Nair PKR (1997) Directions in tropical agroforestry research: past, present, and future. Agrofor Sys 38:223-247

Ndufa J K 2001 Nitrogen and Soil Organic Matter Benefits to Maize by Fast-Growing Pure and Mixed Species Legume Fallows in Western Kenya. $\mathrm{PhD}$ thesis, Imperial College at Wye, University of London, Wye, Ashford, Kent

Parton WJ, Schimel DS, Cole CV, Ojima DS (1987) Analysis of factors controlling soil organic matter levels in Great Plains Grasslands. Soil Sci Soc Am J 51:1173-1179

Rowe EC, Hairiah K, Giller KE, Van Noordwijk M, Cadisch G (1998) Testing the safetynet role of hedgerow tree roots by ${ }^{15} \mathrm{~N}$ placement at different soil depths. Agrofor Sys 43:81-93

Rykiel EJ (1996) Testing ecological models: the meaning of validation. Ecol Modelling 90:229-244

Sanchez PA (1999) Improved fallows come of age in the tropics. Agrofor Sys 47:3-13

Shepherd KD (2004) Predicting decomposition rates of organic resources using near infrared spectroscopy. In: Delve RJ, Probert ME (eds) Modelling nutrient management in tropical cropping systems. ACIAR, Canberra, Australia, p 138

Shepherd KD, Ohlsson E, Okalebo JR, Ndufa JK (1996) Potential impact of agroforestry on soil nutrient balances at the farm scale in the East African Highlands. Fertilizer Res 44:87-99

Shepherd KD, Swinkels RA, Muturi WM, Ohlsson E, Ndufa JK (1992) Evaluation of hedgerow intercropping on farms in western Kenya. I. Diagnosis of technology potential and farmers' interest. Rep. No. 50, International Centre for Research in Agroforestry (ICRAF), Nairobi, Kenya

Sitompul SM, Hairiah K, Cadisch G, van Noordwijk M (2000) Dynamics of density fractions of macro-organic matter after forest conversion to sugarcane and woodlots, accounted for in a modified CENTURY model. Netherlands J Agric Sci 48:61-73

STELLA (1994) STELLA II technical documentation. High Performance Systems Inc., Hanover, USA

Swinkels R, Franzel S (1997) Adoption potential of hedgerow intercropping in maize-based cropping systems in the highlands of Western Kenya. 2. Economic and farmers' evaluation. Exp Agric 33:211-223

Szott LT, Palm CA, Buresh RJ (1999) Ecosystem fertility and fallow function in the humid and subhumid tropics. Agrofor Sys 47:163-197

Valentin C, Rajot JL, Mitja D (2005) Responses of soil crusting, runoff and erosion to fallowing in the sub-humid and semi-arid regions of West Africa. Agric, Ecosys Environ 104:287-302

Van Genuchten MT (1980) A closed-form equation for predicting the hydraulic conductivity of unsaturated soils. Soil Sci Soc Am J 44:892-898 
Van Noordwijk M, Lusiana B (1999) WaNuLCAS, a model of water, nutrient and light capture in agroforestry systems. Agrofor Sys 43:217-242

Van Noordwijk M, Lusiana B, Khahasanah N (2004) WaNuLCAS version 3.1, Background on a model of water nutrient and light capture in agroforestry systems. International Centre for Research in Agroforestry (ICRAF), Bogor, Indonesia

Van Noordwijk M, Mulia R (2005) Press Functional branch analysis as tool for fractal scaling above- and belowground trees for their additive and non-additive properties. Ecol Model 149:41-51

Van Noordwijk M, van de Geijn SC (1996) Root, Shoot and soil parameters required for process oriented models of crop growth limited by water or nutrients. Plant Soil 183:1-25

Woomer PL (1993) Modelling soil organic matter dynamics in tropical ecosystems: Model adoption, uses and limitations. In: Mulongoy K, Merckx R (eds) Soil organic matter dynamics and sustainability of tropical agriculture. John Wiley \& Sons, Leuven, Belgium, pp 279-294

Wösten JHM, Lilly A, Nemes A and Le Bas C (1998) Using existing soil data to derive hydraulic parameters for simulation models in environmental studies and in land use planning. Report 156, SC-DLO, Wageningen (the Netherlands), p 106 